\title{
Mycorrhizal dependence of citrus rootstock
}

\author{
Priscila Batista Miranda ${ }^{1}$, Andrea Hentz de Mello ${ }^{2}$, Katia Cristina Kupper ${ }^{3}$
}

Abstract - Plant growth promoting microorganisms, such as mycorrhizal fungi, have been widely used in agriculture because they help plants in the absorption of nutrients and water, influencing their growth. The objective of this work was to verify the effect of the mycorrhizal association of Glomus clarum and Glomus etunicatum on the initial growth of the rootstocks Rangpur lime, Swingle citrumelo and Sunki mandarin. The experimental design was completely randomized with a $3 \times 4$ factorial arrangement, with five replications, corresponding to three rootstocks, four managements: mineral fertilization, inoculation with G. clarum (IGC), inoculation with G. etunicatum (IGE) and Control. The seedlings were produced in greenhouse, using as substrate the vermicompost earthworm, distributed in polyethylene bags, depositing three seeds of each rootstock / bag. The inoculation with mycorrhizal fungi was carried out at the time of sowing (45 spores of each species / bag). The mineral fertilization was divided into two phases: phosphorus application before sowing ( $40 \mathrm{~g}$ of single superphosphate / bag); nitrogen application ( $1.7 \mathrm{~g}$ dissolved in $40 \mathrm{ml}$ of water), divided in eight applications of $5 \mathrm{ml}$ of the solution, via irrigation water, manually and weekly; and micronutrients (B, $\mathrm{Cu}, \mathrm{Fe}, \mathrm{Mn}$ and $\mathrm{Zn}$ ), sprayed manually every two weeks. The following parameters were evaluated: height, stem diameter, number of leaves, shoot dry mass, colonization and mycorrhizal dependence. There was a significant interaction between the rootstocks and treatments applied in this study for most of the evaluated variables. Rangpur lime and Swingle citrumelo obtained higher height and the management that conferred higher height to the rootstocks was the mineral fertilization and IGE. The largest diameter of the stem was reached by Swingle citrumelo and the management that provided the largest diameter was the inoculation with G. etunicatum. Rangpur lime presented moderate mycorrhizal dependence for G. clarum and marginal for G. etunicatum. Mycorrhizal colonization did not show a significant interaction between rootstocks and the management with inoculation. The mycorrhizal association of G. clarum and G. etunicatum was not presented as the best management for the growth of Rangpur lime, Swingle citrumelo and Sunki mandarin, when compared to the mineral fertilization. However, the inoculation of mycorrhizal fungi provided a positive effect on the uptake of some nutrients by the rootstocks, especially $\mathrm{K}, \mathrm{Mg}, \mathrm{N}$ and $\mathrm{P}$.

Index terms: Mycorrhizal Association, Rangpur lime, Swingle citrumelo, Sunki mandarin.

\section{Dependência micorrízica de porta-enxertos de citros}

Corresponding author: katia@ccsm.br

Received: May 11, 2017. Accepted : November 28, 2017.

Copyright: All the contents of this journal, except where otherwise noted, is licensed under a Creative Commons Attribution License.

\section{(cc) $\mathrm{EY}$}

Resumo - Os microrganismos promotores de crescimento de plantas, como os fungos micorrízicos, têm sido muito utilizados na agricultura, por auxiliarem os vegetais na absorção de nutrientes e de água, influenciando no crescimento destes. Objetivou-se com este trabalho verificar os efeitos da associação micorrízica de Glomus clarum e Glomus etunicatum no crescimento inicial dos porta-enxertos Limão- cravo, Citrumelo swingle e Tangerina sunki. O delineamento experimental foi o inteiramente casualizado,em arranjo fatorial $3 \times 4$, com cinco repetições, correspondendo a três porta-enxertos, quatro manejos, sendo os manejos: adubação mineral (ADB), inoculação com Glomus clarum (IGC), inoculação com Glomus etunicatum (IGE) e Controle. As mudas foram produzidas em estufa, utilizando como substrato vermicomposto de minhoca, distribuído em sacos de polietileno, depositando-se três sementes de cada porta-enxerto/saco. A inoculação com os fungos micorrízicos foi realizada no momento da semeadura (45 esporos de cada espécie/saco). A adubação mineral foi dividida em dois momentos: aplicação de fósforo antes da semeadura ( $40 \mathrm{~g}$ de superfosfato simples/saco); aplicação de nitrogênio (1,7g dissolvidos em $40 \mathrm{~mL}$ de água), parcelado em oito aplicações de $5 \mathrm{~mL}$ da solução, via água de irrigação, manualmente, de forma semanal; e micronutrientes ( $\mathrm{B}, \mathrm{Cu}, \mathrm{Fe}, \mathrm{Mn}$ e $\mathrm{Zn}$ ), aplicados com pulverizador manual, quinzenalmente. Foram avaliados altura, diâmetro do caule, número de folhas, massa seca da parte aérea e colonização, e dependência micorrízica. Verificou-se interação significativa entre os porta-enxertos e os manejos aplicados neste estudo, para a maioria das variáveis avaliadas. Limão cravo e Citrumelo swingle obtiveram maior altura, e o manejo que conferiu maior altura, aos porta-enxertos foram o ADB e o IGE. O maior diâmetro do caule foi atingido pelo Citrumelo swingle, e o manejo que proporcionou maior diâmetro foi o de IGE. Limão cravo apresentou dependência micorrízica moderada para Glomus clarum e marginal para G. etunicatum. A colonização micorrízica não apresentou interação significativa entre os porta-enxertos e os manejos com inoculação. A associação micorrízica de G. clarum e G. etunicatum não se apresentou como o melhor manejo para o crescimento das plantas de Limão-cravo, Citrumelo swingle e Tangerina sunki, quando comparado com a adubação mineral. No entanto, a inoculação de fungos micorrízicos proporcionou um efeito positivo na absorção de alguns nutrientes pelos porta-enxertos, especialmente, de K, Mg, $\mathrm{N}$ e $\mathrm{P}$.

Termos para indexação: Associação micorrízica, Limão cravo, Citrumelo swingle, Tangerina sunki.

\footnotetext{
${ }^{1}$ Master in Agroecology and Rural Development Program, Universidade Federal de São Carlos, Araras, SP. E-mail: engagro.priscila@outlook.com ${ }^{2}$ Doctor of Instituto de Estudos em Desenvolvimento Agrário e Regional, Universidade Federal do Sul e Sudeste do Pará. E-mail: andreahentz@unifesspa.edu.br ${ }^{3}$ Doctor and professor of Agroecology and Rural Development Program, Universidade Federal de São Carlos, Araras, SP. and researcher of Centro Apta Citros Sylvio Moreira/IAC, Cordeirópolis-SP. E-mail: katia@ccsm.br
} 


\section{Introduction}

Citriculture has been highlighted as an important activity of the Brazilian agricultural sector, accounting for $60 \%$ of the world's orange juice production (BRASIL, 2016). The national production is $15,952,253$ tons and the state of São Paulo is the main producer, with 11,642,000 tons, corresponding to approximately $73 \%$ of the total orange produced in the country (IBGE, 2016).

Rangpur lime (C. limonia Osb.) is the most widely used rootstock for the production of citrus seedlings in Brazil (KOLLER; SOPRANO, 2013). Its characteristics such as high vigor, tolerance to water stress, easy seed acquisition, great vigor in the nursery, good establishment of seedlings, rapid growth, high and early production, make this rootstock to be used in about $80 \%$ of citrus orchards (BASTOS et al., 2014).

Sunki mandarin has high vigor, good fruit yield, resistance to tristeza (caused by Citrus tristeza virus), decline and citrus sudden death, being also tolerant to drought (BASSANEZI et al., 2002; POMPEU JUNIOR, 2005). Swingle citrumelo rootstock is considered tolerant to tristeza virus, gummosis, nematode, cold (BASTOS et al., 2014) and citrus sudden death (KUPPER et al., 2016). Such characteristics make the use of these rootstocks relevant for the production of citrus seedlings.

Several studies have been carried out in order to incorporate the use of biological inputs in agriculture, such as the use of plant growth promoting microorganisms (FLORES-AYALAS et al., 2003; LIMA et al., MIRANDA et al., 2016). However, most of these studies use microorganisms as a complementary input to reduce the addition of mineral fertilizers, especially phosphorus, in the processes of seedling production. Thus, studies should be carried out in order to evaluate the isolated effect of these microorganisms and the dependence of plants on them.

Arbuscular mycorrhizal fungi (AMFs) belonging to phylum Glomeromycota stand out as growth promoting microorganisms, which associate with the roots of plants (SCHÜBLER et al., 2001). Arbuscular mycorrhizae are nutritional mutual associations, where the plant supplies the fungus with energy for its growth and maintenance via photosynthetic products, and the fungus provides the plant with better absorption of nutrients and water (BERBARA et al., 2006).

Numerous studies have been carried out in order to prove the efficiency of mycorrhization in several crops, evidencing the increment in the development of plants inoculated with AMFs, to the detriment of those not inoculated, presenting significant gains in growth and absorption of nutrients, especially phosphorus, due to the increase of the area of root absorption, with their extension by AMFs (BALOTA et al., 2011, FERREIRA et al., 2015, GARCIA et al., 2016).
In view of the above, this work aimed to verify the effects of mycorrhizal association of Glomus clarum Nicol. \& Schenck and Glomus etunicatum Becker \& Gerd. on the initial growth of Rangpur lime (Citrus limonia Osbeck), Swingle citrumelo (Citrus paradisi Macf x Poncirus trifoliata (L) Raf.) and Sunki mandarin (Citrus sunki Hort. ex Tan.) rootstocks.

\section{Material and Methods}

The experiment was carried out from March to October 2016 at the greenhouse of the Faculty of Agrarian Sciences of Marabá (FCAM), Federal University of Southern and Southeastern Pará (Unifesspa), located in the municipality of Marabá - PA, Brazil.

This study had a completely randomized design in a $3 \times 4$ factorial scheme with 5 replicates, corresponding to 3 rootstocks (Rangpur lime, Swingle citrumelo and Sunki mandarin) and 4 managements (mineral fertilization - MF, inoculation with Glomus clarum - IGC, inoculation with Glomus etunicatum - IGE and Control, without fertilization and inoculation).

Spores, obtained from FCAM / Unifesspa's Inoculum Bank, were extracted and separated at the laboratory by means of the wet sieving technique (GERDEMANN; NICOLSON, 1963) and centrifugation in water and 40\% sucrose (JENKINS, 1964). After extraction, spores were inoculated in plastic pots of black coloration, with no drainage layer, and capacity of $1 \mathrm{~kg}$, containing autoclaved sand as substrate, in which Brachiaria brizantha was sown. Each AMF species contained three pots as trap cultivation, which remained for 120 days in benches inside a greenhouse with plastic cover and lateral anti-aphid screen.

The substrate used for seedling production was Eisenia foetida vermicompost, whose characteristics, after chemical analysis were: $\mathrm{pH}$ (water) $=6.6$; organic matter $=2.9 \mathrm{dag} / \mathrm{kg}$; cation exchange capacity $=8.9 \mathrm{cmol} / \mathrm{dm}^{3}$; $\mathrm{Mg}=0.7 \mathrm{cmol} / \mathrm{dm}^{3} ; \mathrm{Ca}=5.1 \mathrm{cmol} / \mathrm{dm}^{3} ; \mathrm{P}=158 \mathrm{mg} /$ $\mathrm{dm}^{3} ; \mathrm{K}=650 \mathrm{mg} / \mathrm{dm}^{3} ; \mathrm{S}=25 \mathrm{mg} / \mathrm{dm}^{3} ; \mathrm{Cu}=3.2 \mathrm{mg} /$ $\mathrm{dm}^{3} ; \mathrm{Fe}=236 \mathrm{mg} / \mathrm{dm}^{3} ; \mathrm{Mn}=48 \mathrm{mg} / \mathrm{dm}^{3} ; \mathrm{Zn}=9.5 \mathrm{mg}$ $/ \mathrm{dm}^{3} ; \mathrm{B}=0.47 \mathrm{mg} / \mathrm{dm}^{3}$. The substrate was autoclaved for 20 minutes at pressure of $1 \mathrm{~atm}$ or $1 \mathrm{kgf} / \mathrm{cm}^{2}$, three times, in order to eliminate organisms that could compete with AMFs used, interfering in the results.

For seedling production, rootstock seeds were firstly prepared, washed in running water and immersed in water heated at $50^{\circ} \mathrm{C}$ for 10 minutes. The seed coat was also manually removed. Subsequently, seeds were sown on the substrate at a depth of approximately $3 \mathrm{~cm}$ in black polyethylene bags with capacity of $50 \mathrm{~cm}^{3}$, depositing three seeds of each rootstock per bag. Pots were kept on benches throughout the experimental period. Before sowing, the substrate was treated with the different isolates 
of mycorrhizal fungi and / or mineral fertilization.

The two managements with inoculation consisted of depositing 45 spores of each AMF species in a hole made at the center of the substrate of approximately $3 \mathrm{~cm}$ in depth and $3 \mathrm{~cm}$ in diameter.

The management with mineral fertilization was carried out in two stages. In the first, a source of phosphorus (P), in the form of single superphosphate (SS - $16 \%$ of $\mathrm{P}_{2} \mathrm{O}_{5}$ ) was added, homogenizing $40 \mathrm{~g}$ of fertilizer with substrate contained in each container, prior to sowing. The second stage was carried out after 30 days from the emergence of cotyledons, in which pruning and application of nitrogen $(\mathrm{N})$ and micronutrients $(\mathrm{B}, \mathrm{Cu}$, $\mathrm{Fe}, \mathrm{Mn}$ and $\mathrm{Zn}$ ) were performed. A total of $1.7 \mathrm{~g}$ of $\mathrm{N}$, dissolved in $40 \mathrm{ml}$ of water, was applied in a split - plot scheme, consisting of eight weekly applications of urea cover, via manual irrigation water. Therefore, $5 \mathrm{ml}$ of this solution were applied near the root of each seedling (DECARLOS NETO et al., 2002). The micronutrients, in turn, were sprayed with a manual sprayer only on the shoots, every two weeks, according to recommendation of EMBRAPA (2003).

At 30,60 and 90 days after the emergence of plants, the following growth parameters were evaluated: shoot height, number of leaves and stem diameter $(\mathrm{cm})$. To measure height, a ruler graduated in millimeters was used and for stem diameter, a universal caliper graduated in millimeters was used.

After 90 days, plants were collected and evaluated for shoot dry mass (g), mycorrhizal dependence and colonization. In order to determine the weight of the shoot dry mass (SDM), seedlings had the leaves and branches separated from the root and this material was taken to the oven with air circulation at $65^{\circ} \mathrm{C}$ for 48 hours until reaching constant weight.

The mycorrhizal dependence was calculated for each management with inoculation through formula suggested by Plenchette et al. (1983):

$$
\mathrm{MD}=\underline{\mathrm{DBMP}}-\mathrm{DBNMP} \times 100
$$

\section{DBMP}

Where: $\mathrm{MD}=$ mycorrhizal dependence; $\mathrm{DBMP}=$ dry biomass of mycorrhizal plants; DBNMP = dry biomass of non-mycorrhized plants.

In order to classify mycorrhizal dependence, the following categories adapted from Habte and Manjunath (1991) were used: overly dependent plants (MD > 75\%), highly dependent plants (50-75\%), moderately dependent plants $(25-50 \%)$, marginally dependent $(<25 \%)$ or independent (do not respond to mycorrhization).

To obtain the percentage of mycorrhizal colonization, roots were collected, washed and stained by the staining and clarification method of Phillips and Hayman (1970).
Colonization quantification was performed by the quadrant intersection method of Giovannetti and Mosse (1980).

Data were submitted to analysis of variance and means were compared by the Tukey's test at 5\% probability, using the Assistat 7.7 software (SILVA; AZEVEDO, 2016).

\section{Results and discussion}

There was a significant interaction between rootstocks and managements for the shoot height variable (Table 1). The highest averages of this variable were reached by Rangpur lime and Swingle citrumelo plants (Table 2) and the management that provided the highest height to plants was mineral fertilization and inoculation with $G$. etunicatum, although the last treatment was not statistically different from G. clarum inoculation and control (Table 3).

Melloni et al. (2000) verified result similar to this in relation to Glomus etunicatum in an experiment with Rangpur lime rootstock cultivated in substrate with different P levels. The authors found that this AMF was not efficient in promoting the increase in the mean values of the evaluated variables, not differing from control. However, in the same research, they demonstrated that Rangpur lime depended on mycorrhization with Glomus intraradices to reach higher height, stem diameter and shoot dry matter.

There was a significant interaction between rootstocks and treatments for the stem diameter variable (Table 4). The highest mean of this variable was obtained by Swingle citrumelo (Table 5) and the management that attributed the largest diameter to the rootstocks was that in which Glomus etunicatum was used (Table 6).

There was no significant interaction between rootstocks and managements, when the number of leaves was evaluated (Table 7). However, the management that provided the highest average number of leaves to plants was that of mineral fertilization (Table 8).

In relation to shoot dry mass (SDM) (Figure 1), mineral fertilization was the management that resulted in higher averages for all rootstocks. Swingle citrumelo presented the highest SDM values, considering all the treatments applied.

Inoculation with G. etunicatum favored the growth of rootstocks, considering the height and stem diameter variables, unlike $G$. clarum, which did not promote the growth of plants in any of the variables analyzed. Back et al. (2016), working with 'Kumquateiro' [Fortunella hindsii (L.) Swingle] and 'Fepagro C37 Reck' citrange [P. trifoliate (L.) Raf. C. sinensis (L.) Osbeck.] citrus rootstocks inoculated with three different species of mycorrhizal fungi, found that G. etunicatum was efficient in accelerating the growth of 'Fepagro C37 Reck'. This result corroborates those obtained in this study related 
to the ability of $G$. etunicatum to promote the growth of citrus rootstocks.

Considering that AMFs benefit better species when they are found on substrates with low P levels (MOREIRA SOUZA; CARDOZO, 2002), this behavior, in relation to G. clarum, may be related to the fertility level presented by the substrate at the beginning of seedling production, which had a considerable $\mathrm{P}$ content (158 mg / $\mathrm{dm}^{-3}$ ), and $\mathrm{pH}$ close to neutrality (6.6).

Likewise, Balota et al. (2011), studying acerola (Malpighia emarginata DC) associated with AMFs and phosphorus addition, showed that the increased incorporation of $\mathrm{P}$ in the soil allowed significant increase in the biomass of plants and reduced the root colonization and sporulation of AMFs, and the high mycorrhizal dependence of this plant occurred in soil with low P level (7 mg / kg $\left.{ }^{-1}\right)$. Machineski et al. (2011) observed higher number of $G$. clarum spores at P level of $20 \mathrm{mg} \mathrm{kg}^{-1}$, and $60 \mathrm{mg} \mathrm{kg}^{1}$ for $G$. margarita, favoring increases in the dry mass of castor bean at lower P levels in the soil.

In relation to mycorrhizal dependence, Rangpur lime presented a dependence of $33.11 \%$ when inoculated with Glomus clarum and $14.88 \%$ when inoculated with Glomus etunicatum (Table 9). According to the classification of Habte and Manjunath (1991), these values express moderate mycorrhizal dependence (25-50\%) for G. clarum and marginal $(<25 \%)$ for $G$. etunicatum, while the other rootstocks presented marginal dependence to these mycorrhizal fungi. However, these values allow affirming that the rootstocks presented low mycorrhizal dependence, and that the substrate fertility was sufficient to promote greater growth of plants.

Thus, mycorrhizal fungi do not have host specificities, that is, a plant species can form a mycorrhizal association with the most diverse species of AMFs, but the results of this symbiosis can vary according to the fungus-soil-plant interaction (CAVALCANTE et al., 2009), which depends on the need of nutrient uptake by the host and their available amounts, especially $\mathrm{P}$, in the soil (HIPPLER, MOREIRA, 2013; SENNA et al., 2014), as well as water content, $\mathrm{pH}$, salinity, temperature, among other environmental factors (MEHROTA, 2005).

In relation to the percentage of mycorrhizal colonization, there was no significant interaction between rootstocks and inoculation with Glomus clarum and Glomus etunicatum (Table 10). Nunes et al. (2006) evaluated the mycorrhizal colonization of citrus rootstocks and found that at higher $\mathrm{P}$ levels, the colonization rate decreased for some rootstocks. Similarly, in non-fertilized soil with low P levels, the effects of mycorrhization were more satisfactory for Annona squamosa L., Annonaceae (COELHO et al., 2012) in non-fertilized soil with low $\mathrm{P}$ content. These results may explain that the low colonization rate was due to the high amount of $\mathrm{P}$ in the substrate.

The results obtained in this study allow concluding that each plant species may have different interactions, when associated with several AMFs, even when submitted to the same environmental conditions. According to Melo et al. (2016), citrus varieties can affect the amount of AMFs and $\mathrm{P}$ solubilizers in the rhizosphere. According to the authors, the six citrus varieties evaluated in their research (Pera D9, Rubi, Pineaple, Pera D12, Page and Pera C21) were all colonized by mycorrhizal fungi, but the Page variety had higher number of glomerospores and Pineaple, higher number of colony forming units (CFU / $\mathrm{mL}$ ) of total fungi.

In this study, rootstocks had little dependence on mycorrhizal fungi, but high on substrate fertility. However, several studies have shown that there is a significant compatibility of citrus in association with AMFs (MELLONI et al., 2000; DECARLOS NETO et al., 2002; NUNES et al., 2006).

Therefore, it could be concluded that the fertility of the substrate to be used, especially with respect to phosphorus, should be an important factor to be considered when studying the mycorrhizal dependence of plant species, since its maximum or minimum amounts has influence proportionally inverse to the mycorrhization.

Table 1. Analysis of Variance for the height of rootstocks Rangpur lime, Swingle citrumelo and Sunki mandarin submitted to the management with mineral fertilization, inoculation with Glomus clarum, inoculation with Glomus etunicatum and control at 90 days of evaluation.

\begin{tabular}{ccccc}
\hline SV & DF & SS & AS & F \\
\hline Rootstocks & 2 & 152.79433 & 76.39717 & $14.0238^{* *}$ \\
Managements & 4 & 131.36733 & 43.78911 & $8.0381^{* *}$ \\
Rootstocks x Managements & 6 & 156.69767 & 26.11628 & $4.7940 * *$ \\
\hline Treatments & 11 & 440.85933 & 40.07812 & $7.3569 * *$ \\
Residue & 48 & 261.48800 & 5.44767 & \\
\hline Total & 59 & 702.34733 & &
\end{tabular}

** Significantly at $1 \%$ of probability $(\mathrm{p}<0.01) \mathrm{SV}=$ source of variation; $\mathrm{DF}=$ degree of freedom; $\mathrm{SS}=$ sum of squares; $\mathrm{AS}=$ average square; $\mathrm{F}=F$ test. 
Table 2. Averages of the height variable for rootstocks Rangpur lime, Swingle citrumelo and Sunki mandarin, submitted to the management with mineral fertilization, inoculation with Glomus clarum, inoculation with Glomus etunicatum and control at 90 days.

\begin{tabular}{cc}
\hline Rootstocks & Averages $(\mathbf{c m})$ \\
\hline Rangpur lime & $11.62 \mathrm{a}^{*}$ \\
Swingle citrumelo & $11.99 \mathrm{a}$ \\
Sunki mandarin & $8.43 \mathrm{~b}$ \\
${ }^{*}$ Means followed by the same letter in the column are not significantly different according to Tukey's test at $5 \%$ of probability.
\end{tabular}

Table 3. Averages of the height provided by the managements with mineral fertilization, inoculation with Glomus clarum, inoculation with Glomus etunicatum and control, applied to the rootstocks, at 90 days of evaluation.

\begin{tabular}{cc}
\hline Managements & Averages (cm) \\
\hline Mineral fertilization & $13.00 \mathrm{a}^{*}$ \\
Glomus clarum & $9.08 \mathrm{~b}$ \\
Glomus etunicatum & $10.82 \mathrm{ab}$ \\
Control & $9.79 \mathrm{~b}$ \\
${ }^{(*)}$ Means followed by the same letter in the column are not significantly different according to Tukey's test at $5 \%$ of probability.
\end{tabular}

Table 4. Analysis of Variance for stem diameter $(\mathrm{cm})$ of the rootstocks Rangpur lime, Swingle citrumelo and Sunki mandarin submitted to the management with mineral fertilization, inoculation with Glomus clarum, inoculation with Glomus etunicatum and control at 90 days.

\begin{tabular}{ccccc}
\hline SV & DF & SS & AS & F \\
\hline Rootstocks & 2 & 0.09433 & 0.04717 & $40.42 .86^{* *}$ \\
Managements & 4 & 0.05000 & 0.01667 & $14.2857^{* *}$ \\
Rootstocks x Managements & 6 & 0.02300 & 0.00383 & $3.2857^{* *}$ \\
\hline Treatments & 11 & 0.16733 & 0.01521 & $13.0390^{* *}$ \\
Residue & 48 & 0.05600 & 0.00117 & \\
\hline Total & 59 & 0.22333 & & \\
\hline
\end{tabular}

** Significantly at $1 \%$ of probability $(\mathrm{p}<0.01) \mathrm{SV}=$ source of variation; $\mathrm{DF}=$ degree of freedom; $\mathrm{SS}=$ sum of squares; AS = average square; $\mathrm{F}=F$ test.

Table 5. Averages of the stem diameter variable for rootstocks Rangpur lime, Swingle citrumelo and Sunki mandarin, submitted to the management with mineral fertilization, inoculation with Glomus clarum, inoculation with Glomus etunicatum and control at 90 days.

\begin{tabular}{cc}
\hline Rootstocks & Averages (cm) \\
\hline Rangpur lime & $0.29 \mathrm{~b}^{*}$ \\
Swingle citrumelo & $0.32 \mathrm{a}$ \\
Sunki mandarin & $0.23 \mathrm{c}$ \\
\hline
\end{tabular}

${ }^{(*)}$ Means followed by the same letter in the column are not significantly different according to Tukey's test at $5 \%$ of probability.

Table 6. Averages of the stem diameter provided by the managements with mineral fertilization, inoculation with Glomus clarum, inoculation with Glomus etunicatum and control, applied to the rootstocks, at 90 days of evaluation.

\begin{tabular}{cc}
\hline Manejos & Averages $\mathbf{( c m})$ \\
\hline Mineral fertilization & $0.26 \mathrm{~b}^{*}$ \\
Glomus clarum & $0.26 \mathrm{~b}$ \\
Glomus etunicatum & $0.33 \mathrm{a}$ \\
Control & $0.26 \mathrm{~b}$ \\
\hline
\end{tabular}

${ }^{(*)}$ Means followed by the same letter in the column are not significantly different according to Tukey's test at $5 \%$ of probability. 
Table 7. Analysis of Variance for number of leaves of the rootstocks Rangpur lime, Swingle citrumelo and Sunki mandarin submitted to the management with mineral fertilization, inoculation with Glomus clarum, inoculation with Glomus etunicatum and control at 90 days.

\begin{tabular}{ccccc}
\hline SV & DF & SS & AS & F \\
\hline Rootstocks & 2 & 28.03333 & 14.01667 & $0.8397 \mathrm{~ns}$ \\
Managements & 4 & 1213.93333 & 202.64444 & $24.2423 * *$ \\
Rootstocks x Managements & 6 & 152.76667 & 25.46111 & $1.5254 \mathrm{~ns}$ \\
\hline Treatments & 11 & 1394.73333 & 126.79394 & 7.5962 \\
Residue & 48 & 801.20000 & 16.69167 & \\
\hline Total & 59 & 2195.93333 & &
\end{tabular}

** Significantly at $1 \%$ of probability $(\mathrm{p}<0.01) ; \mathrm{ns}=$ not significant $(\mathrm{p}>=0.05) ; \mathrm{SV}=$ source of variation; DF = degree of freedom; $\mathrm{SS}=$ sum of squares; $\mathrm{AS}=$ average square; $\mathrm{F}=F$ test.

Table 8. Averages of the number of leaves provided by the managements with mineral fertilization, inoculation with Glomus clarum, inoculation with Glomus etunicatum and control, applied to the rootstocks, at 90 days of evaluation.

\begin{tabular}{cc}
\hline Manejos & Médias \\
\hline Mineral fertilization & $16.80 \mathrm{a}^{*}$ \\
Glomus clarum & $6.46 \mathrm{~b}$ \\
Glomus etunicatum & $5.93 \mathrm{~b}$ \\
Control & $6.93 \mathrm{~b}$ \\
\hline
\end{tabular}

${ }^{(*)}$ Means followed by the same letter in the column are not significantly different according to Tukey's test at $5 \%$ of probability.

Table 9. Mycorrhizal dependence of the rootstocks regarding the AMFs Glomus clarum and Glomus etunicatum.

\begin{tabular}{cccc}
\hline Porta-enxertos & Control & Glomus clarum & Glomus etunicatum \\
\hline & & $\%$ & \\
\hline Rangpur lime & 0 & 33.11 & 14.88 \\
Swingle citrumelo & 0 & 3.21 & 7.86 \\
Sunki mandarin & 0 & 3.22 & 5.73 \\
\hline
\end{tabular}

Table 10. Analysis of Variance for mycorrhizal colonization of the rootstocks Rangpur lime, Swingle citrumelo and Sunki mandarin, submitted to the inoculation with Glomus clarum and Glomus etunicatum at 90 days.

\begin{tabular}{ccccc}
\hline SV & DF & SS & AS & F \\
\hline Rootstocks & 2 & 0.20192 & 0.10096 & $2.5161^{\text {ns }}$ \\
Managements & 1 & 0.00108 & 0.00108 & $0.0269^{\text {ns }}$ \\
Rootstocks x Managements & 2 & 0.17192 & 0.08596 & $2.1423^{\text {ns }}$ \\
\hline Treatments & 5 & 0.37492 & 0.07498 & $1.8688^{\text {ns }}$ \\
Residue & 24 & 0.96300 & 0.04013 & \\
\hline Total & 29 & 1.33792 & & \\
\hline
\end{tabular}

$*_{\mathrm{ns}}=$ not significant $(\mathrm{p}>=0.05) ; \mathrm{SV}=$ source of variation; $\mathrm{DF}=$ degree of freedom; $\mathrm{SS}=$ sum of squares; $\mathrm{AS}=$ average square; $\mathrm{F}=F$ test. 


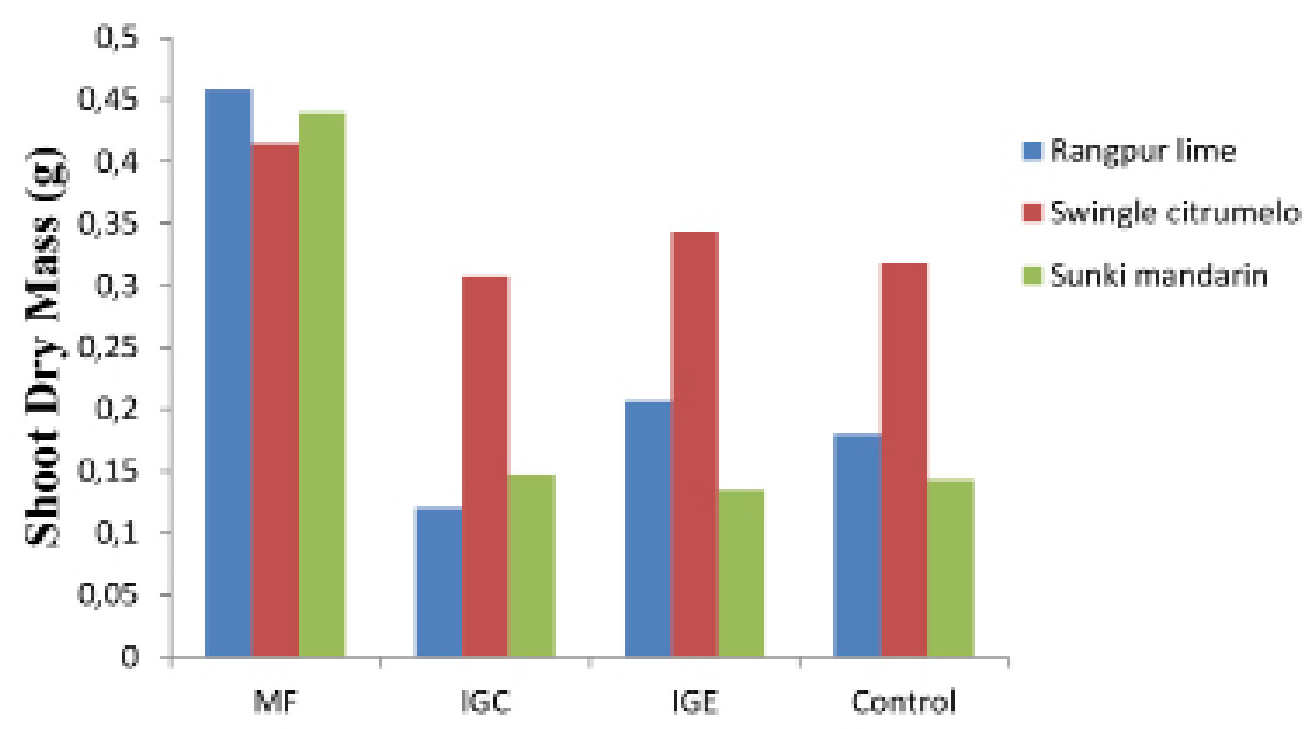

Figure 1. Shoot Dry Mass (g) of the of the rootstocks Rangpur lime, Swingle citrumelo and Sunki mandarin, submitted to the management with mineral fertilization (MF), inoculation with Glomus clarum (IGC), inoculation with Glomus etunicatum (IGE) and control at 90 days.

\section{Conclusion}

The mycorrhizal association of Glomus clarum and G. etunicatum was not presented as the best management for the growth of Rangpur lime, Swingle citrumelo and Sunki mandarin plants when compared to mineral fertilization. However, the inoculation of mycorrhizal fungi provided a positive effect on the uptake of some nutrients by rootstocks, especially $\mathrm{K}, \mathrm{Mg}, \mathrm{N}$ and $\mathrm{P}$.

\section{References}

BACK, M.M.; ALTMANN, T.; SOUZA, P.V.D.Influence of arbuscular mycorrhizal fungi on the vegetative development of citrus rootstocks1.Pesquisa Agropecuária Tropical, Goiânia, v.46, n.4, p.407-412, 2016. Disponível em: $\leq$ http://www.scielo.br/scielo.php?script=sci arttext\&pid $=$ S1983-40632016000400407\&lng=en\&nrm =iso>. Acesso em: 09 out. 2017.

BALOTA, E.L.; MACHINESKI, O.; STENZEL, N.M.C. Resposta da acerola à inoculação de fungos micorrízicos arbusculares em solo com diferentes níveis de fósforo. Bragantia, Campinas, v.70, n.1, p.166-175, 2011. Disponível em <http://www. scielo.br/scielo.php?script $=$ sci arttext\&pid $=$ S0006$\underline{87052011000100023 \& \operatorname{lng}=p t \& n r m=i s o>}$. Acesso em: 03 jan. 2017.

BASSANEZI, R.B.; GIMENES-FERNANDES, N.; MASSARI, C.A. Resultados do levantamento detalhado da morte súbita dos citros na região afetada: junho a setembro de 2002. Araraquara: Fundecitrus, 2002. 9p. (Relatório).
BASTOS, D.C.; FERREIRA, E.A.; PASSOS; O.S.; SÁ; J.F.; ATAIIDE, E.M; CALGARO, M. Cultivares copa e porta-enxertos para a citricultura brasileira. Informe Agropecuário, Belo Horizonte, v.35, p.36-45, 2014.

BERBARA, R. L.; SOUZA, F. A.; FONSECA, H. M. A. C. Fungos micorrízicos arbusculares: muito além da nutrição. In: FERNANDES, M.S. (Ed.). Nutrição mineral de plantas. Viçosa: SBCS, 2006. p. 53-85.

BRASIL. Ministério da Agricultura, Pecuária e Abastecimento. Citrus. Brasília, DF, 2016. Disponível em: <http://www.agricultura.gov.br/vegetal/culturas/ citrus $>$. Acesso em: 12 dez. 2016.

CAVALCANTE, U.M.T.; GOTO, B.T.; MAIA, L.C. Aspectos da simbiose micorrízica arbuscular. Anais da Academia Pernambucana de Ciência Agronômica, Recife, v.5/6, p.180-208, 2008/2009. Disponível em: $\leq$ http://www.journals.ufrpe.br/index.php/apca/issue/ view/26 > . Acesso em: 04 de jan. 2017.

COELHO, I. R.; CAVALCANTE, U. M. T.; CAMPOS, M. A. da S.; SILVA, F. S. B. Uso de fungos micorrízicos arbusculares (FMA) na promoção do crescimento de mudas de pinheira (Annona squamosa L., Annonaceae). Acta Botanica Brasilica, Feira de Santana, v. 26, p. 933-937, 2012. Disponível em: $\leq \mathrm{http}: / /$ www. scielo.br/scielo.php?script $=$ sci arttext\&pid $=\mathrm{S} 0102-$ $33062012000400022 \& \operatorname{lng}=$ en $\& n r m=$ iso $>$. Acesso em: 19 maio 2017. 
DECARLOS NETO, A.; SIQUEIRA, D. L. de; PEREIRA, P. R. G.; ALVAREZ V.; V. H. Crescimento de portaenxertos de citros em tubetes influenciados por doses de N. Revista Brasileira de Fruticultura, Jaboticabal, v. 24, n.1, 199-203, 2002. Disponível em: <http://www. scielo.br/scielo.php?script $=$ sci_arttext\&pid $=\mathrm{S} 0100-$ $29452002000100043 \& \operatorname{lng}=$ en\&nrm $=$ iso $>$. Acesso em: 04 jan. 2017.

EMBRAPA- Empresa Brasileira de Pesquisa Agropecuária. Sistema de produção de citros para o Nordeste. Brasília, DF, 2003. Disponível em: $\leq$ https://sistemasdeproducao. cnptia.embrapa.br/FontesHTML/Citros/CitrosNordeste/ index.htm>. Acesso em: 21 dez. 2016.

FERREIRA, G.M.R.; MELLONI, R.; SILVA, L.F.O.; MARTINS, F.B.; GONÇALVES, E.D. Fungos micorrizicos arbusculares no desenvolvimento de mudas de oliveira (Olea europaea L.) Cultivadas no sul de minas gerais. Revista Brasileira de Ciência do Solo, Viçosa, MG, v.39, n.2, p.361-366, 2015. Disponível em: $\leq \mathrm{http}: / / \mathrm{www}$. scielo.br/scielo.php?script $=$ sci_arttext\&pid $=\mathrm{S} 0100$ $06832000000400009 \& \operatorname{lng}=\mathrm{en} \& \mathrm{nrm}=\mathrm{iso}>$. Acesso em: 01 jan. 2017.

FLORES-AYLAS, W.W.; SAGGIN-JUNIOR, O.J.; SIQUEIRA, J.O.; DAVIDE, A.C. Efeito de Glomus etunicatum e fósforo no crescimento inicial de espécies arbóreas em semeadura direta. Pesquisa Agropecuária Brasileira, Brasília, DF, v.38, n.2, p.257-266, 2003.

GARCIA, K.G.V.; GOMES, V.F.F.; ALMEIDA, A.M.M.; FILHO, P.F.M. Micorrizas arbusculares no crescimento de mudas de sabiá em um substrato proveniente da mineração de manganês. Revista Verde de Agroecologia e Desenvolvimento Sustentável, Pombal, v.11, n.2, p.15-20, 2016. Disponível em:<http://www.gvaa.com. br/revista/index.php/RVADS/article/view/4088>. Acesso em: 28 dez. 2016.

GERDEMANN, J.W.; NICOLSON, T.H. Spores of mycorrhizal Endogone species extracted from soil by wt-sieving and decanting. Transactions of Britisch Mycological Society, Cambridge, v.46, p.235-244, 1963.

GIOVANNETTI, M.; MOSSE, B. An evaluation of techniques for measuring vesicular arbuscular mycorrhizal infection in roots. New Phytologist, Cambridge, v.84, p.489-500, 1980.

HABTE, M.; MANJUNATH, A. Categories of vesicular arbuscular mycorrhizal dependency of host species. Mycorrhiza, Berlin, v.1, n.1, p.3-12, 1991.
HIPPLER, F.W.R.; MOREIRA,M. Dependênciamicorrízica do amendoinzeiro sob doses de fósforo. Bragantia, Campinas , v.72, n.2, p.184-191, 2013. Disponível em: $<$ http://www.scielo.br/scielo.php?script=sci arttext\&pid $=$ S0006-87052013000200011\&lng=en\&nrm =iso $>$. Acesso em: 04 jan. 2017.

IBGE - Instituto Brasileiro de Geografia e Estatística. Pesquisa mensal de previsão e acompanhamento das safras agrícolas no ano civil. Levantamento Sistemático da Produção Agrícola, Rio de Janeiro, v.29, n.10, p.1-117, 2016.

JENKINS, W.R. A rapid centrifugal-floration technibique for separating nematodes from soil. Plant Disease Report , Beltsville, v.48, p. 692. 1964.

KOLLER, O.L.; SOPRANO, E. Principais cultivares cítricos. In: KOLLER, O. L.; SOPRANO, E. Citricultura catarinense. Florianópolis: Epagri, 2013. p.57-120.

KUPPER, K.C.; FERRAZ, L.P.; SILVA, A.C.; COLETTA FILHO, H.D. Doenças dos citros. In: EPAMIG. Manejo de doenças de fruteiras de clima temperado, subtropical e tropical. Belo Horizonte, 2016. p.36-53. (Informe Agropecuário, 37)

LIMA, K.B.; RITTER NETTO, A.F.R.; MARTINS, M.A.; FREITAS, M.S.M. Crescimento, acúmulo de nutrientes e fenóis totais de mudas de cedro australiano (Toona ciliata) inoculadas com fungos micorrízicos. Ciência Florestal, Santa Maria, v.25, n.4, p.853-862, 2015.

MACHINESKI, O.; BALOTA, E.L.; SOUZA, R.P. de. Resposta da mamoneira a fungos micorrízicos arbusculares e a níveis de fósforo. Semina: Ciências Agrárias, Londrina, v.32, p.1855-1862, 2011. Suplemento 1. Disponível em: $\leq$ http://www.uel.br/revistas/uel/index. php/semagrarias/article/viewFile/7795/9146>. Acesso em: 30 dez. 2016.

MEHROTA, V.S. Mycorrhizas: role and applications. New Delhi: Allied Publishers, 2005. 355 p.

MELLONI, R.; NOGUEIRA, M.A.; FREIRE, V.F.; CARDOSO, E.J.B.N. Fósforo adicionado e fungos micorrízicos arbusculares no crescimento e nutrição mineral de limoeiro-cravo [Citrus limonia (L.) OSBECK]. Revista Brasileira de Ciência do Solo, Viçosa, MG, v.24, n.4, p.767-775, 2000. Disponível em: $\leq$ http://www. scielo.br/scielo.php?script $=$ sci_arttext\&pid $=\mathrm{S} 0100$ $06832015000200361 \& \operatorname{lng}=\mathrm{en} \& \mathrm{nrm}=\mathrm{iso}>$. Acesso em: 03 jan. 2017. 
MELO, K.G.P.; SILVA, A.R.da S.; YANO-MELO, A.M. Variedades de citrus podem afetar a comunidade de fungos do solo? Comunicata Scientiae, Bom Jesus, vol.7, n.2, p.167-174, 2016. Disponível em: $\leq$ https://comunicatascientiae.com.br/comunicata/article/ viewFile/1763/394> Acesso em: 01 dez. 2017.

MIRANDA, E.M. de; SILVA, E.M.R. da; SAGGIN JUNIOR, O.J. Inoculação micorrízica e adubação fosfatada na produção de mudas de amendoim forrageiro. Revista Ciência Agronômica, Fortaleza, v.47, n.2, p.240246, 2016.

MOREIRA-SOUZA, M.; CARDOZO, E.J.B.N. Dependência micorrízica de Araucaria angustifólia (Bert.) O. Ktze. Sob doses de fósforo. Revista Brasileira de Ciência do Solo, viçosa, MG, v.26, p.905-912, 2002.

NUNES, M. de S.; SOARES, A.C.F.; SOARES FILHO, W. dos S.; LEDO, C.A. da S. Colonização micorrízica natural de porta-enxertos de citros em campo. Pesquisa Agropecuária Brasileira, Brasília, DF, v.41, n.3, p.525528, 2006. Disponível em: $<\mathrm{http} / / / \mathrm{www}$.scielo.br/scielo. php?script $=$ sci arttext\&pid $=\mathrm{S} 0100-204 X 200600030002$

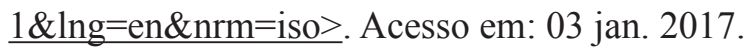

PHILLIPS, J.M.; HAYMAN, D.S. Improved procedures for clearing roots and staining parasitic and vesicular arbuscular mycorrhizal fungi for rapid assessment of infection. Transactions of the British Mycological Society, Cambridge, v.55, p.158-161, 1970.
PLENCHETTE, C.; FORTIN, J. A.; FURLAN, V. Growth of several plant species to mycorrhizae in a soil of moderate P-fertility. Plant and Soil, The Hague, n.70, p.199-209, 1983.

POMPEU JUNIOR, J. Porta-enxertos. In: MATTOS JUNIOR, D.; DE NEGRI, J.D.; PIO, R.M.; POMPEU JUNIOR, J. Citros. Campinas: IAC; Fundag, 2005. cap.4, p. 61-104.

SCHÜßLER, A.; SCHWARZOTT, D.; WALKER, C. A new phylum, the Glomeromycota: phylogeny and evolution. Mycological Research, Amsterdam, v.105, p.1413-1421, 2001.

SENNA, J.O.A. de; STEFANUTTI, R.; DONHA, R.M.A.; CARDOSO, E.J.B.N. Cinética de absorção com doses de fósforo e fungos micorrízicos arbusculares em Nicotiana tabacum. Científica, Jaboticabal, v.42, n.3, p.294-298, 2014.

SILVA, F. de A.S.E.; AZEVEDO, C.A.V. de. The Assistat software version 7.7 and it's use in the analysis of experimental data. African Journal Agricultural Research, Nairobi, v.11, n.39, p.3733-3740, 2016. 